\title{
Productivity:
}

\section{What Is It, and Why Do We Care About It?}

\author{
Charles Steindel \\ and \\ Kevin J. Stiroh*
}

April 12, 2001

\begin{abstract}
Economists, business analysts, and policymakers have all focused considerable attention on U.S. productivity growth in recent years. This paper presents a broad overview of productivity - both labor and total factor - and discusses why it is such an important topic. We begin with the official U.S. productivity statistics prepared by the U.S. Bureau of Labor Statistics and discuss several stylized facts. We show how productivity relates to critically important variables like long-run growth, living standards, and inflation. We then describe the proximate factors that determine labor productivity using a standard growth accounting framework. Finally, we outline a series of unresolved productivity issues that have direct implications for the future of the U.S. economy. JEL Code: $\mathrm{O} 4$.
\end{abstract}

*Steindel is a Senior Vice President and Stiroh a Senior Economist at the Federal Reserve Bank of New York. We acknowledge the assistance of Donald Rissmiller and Theresa Waters, and helpful comments from Erica Groshen and seminar participants at the Federal Reserve Bank of New York. This paper expresses the views of the authors only and not necessarily those of the Federal Reserve Bank of New York or the Federal Reserve System. 


\section{Introduction}

Recent years have seen widespread discussion of productivity, and for good reason. It appears that labor productivity growth has improved sharply, perhaps approaching the pace of the "golden age" of the 1950s and 1960s. To put the importance of this recent change in perspective, consider the direct impact. If labor productivity were to grow at $1.5 \%$ (the average rate from 1973 to 1995), output per hour would rise by 35\% after 20 years. Growth of $2.7 \%$ (the average for 1995-99) implies that it would be $70 \%$ higher after 20 years. Clearly, the rate of productivity growth can have an enormous effect on real output and living standards. ${ }^{1}$

The debate about the sources and sustainability of the recent productivity improvement has often hinged on somewhat obscure concepts such as "cyclical" and "trend" components of productivity, differences between "labor" and "total factor" productivity, and the relative importance of factors like "capital deepening," "spillovers," "productivity of computer output," and "productivity of computer use," etc. Many of these terms are not only similar in wording, but the intellectual differences between them can also be quite subtle.

This paper aims to elucidate the key ideas and concepts in the economic analysis of productivity and apply them to the recent trends. We begin by describing the most commonly used measures of productivity, discuss the importance of productivity for several major economic variables, sketch some of the factors believed to determine productivity, and finally note several open research questions in this area.

\section{What is Productivity?}

This section discusses the most common measures of productivity that are widely used by economists and business analysts, and reviews their most noteworthy empirical characteristics. We start with the most basic concept of labor productivity - defined simply as real output per hour of work. We then deal with the more difficult concept of total factor productivity - defined as real output per unit of all inputs. This reflects, in part, the overall efficiency with which inputs are transformed into outputs and is often associated with technology, but it more accurately reflects the impact of a host of other factors like economies of scale, any unaccounted inputs, resource reallocations, and others. Finally, we review some limitations of these measures.

\footnotetext{
${ }^{1}$ As discussed later, labor productivity growth is a good, although not perfect proxy, for growth in per capita income and rising living standards.
} 


\section{(a) Labor Productivity}

Perhaps the most noted measure of productivity is the Bureau of Labor Statistics' (BLS) series on output per worker-hour for the private nonfarm business economy, an index of labor productivity (BLS, 2000a). Similar measures have been calculated since the 1800s, when Congress expressed concern that human labor was being replaced by industrialized machinery not so different from the concerns of some workers today!

We first examine the evolution of labor productivity in the post-war period. The fourquarter change in private nonfarm labor productivity is plotted in Chart $1 .^{2}$ Two features stand out. First, labor productivity has a very obvious business cycle component; productivity growth is low or negative during recessions and high in the early stages of expansions when the economy is expanding rapidly. This pro-cyclicality of productivity is well known and largely reflects the lack of instantaneous adjustment in factor markets. ${ }^{3}$

Second, looking beyond the cyclical movements, labor productivity growth was decidedly lower in the 20 years or so starting in the early 1970s than in the earlier period. Despite considerable research effort, this "productivity slowdown" remains largely unexplained. ${ }^{4}$ From 1996 onwards, however, there has been a sharp strengthening in productivity growth to rates similar to the earlier period. Table 1 presents the long-period averages of labor productivity growth, with 1973Q4 chosen as the end of the early high-growth period and 1995Q4 chosen as the end of the slow-growth period. ${ }^{5}$

The nonfarm business series is only one of many measures of labor productivity produced by BLS. BLS also produces measures of output per worker hour for all private business (adding back the farms), for nonfinancial corporations, for manufacturing as a whole,

\footnotetext{
${ }^{2}$ This series is usually examined on a four-quarter basis, since it is quite volatile quarter-to-quarter.

${ }^{3}$ Fernald and Basu (1999) attribute this apparent regularity to a combination of pro-cyclical productivity shocks, imperfect competition and increasing returns, variable input utilization, and resource reallocations, with the latter two being particularly important.

${ }^{4}$ See Wolff (1996) for a recent analysis and earlier references.

${ }^{5}$ There is some controversy about the choice of 1973 as the break point in the data. Productivity numbers in the first half of the 1970s were clearly heavily affected by the sharp cyclical swings in the economy and distortions created by the end of the fixed-exchange rate system, the introduction and removal of wage and price controls, and the runup in energy prices. For the purposes of this paper the "traditional" 1973 date, which coincides with the start of the 1973-75 recession, is suitable, but it should not be blindly accepted for serious statistical analysis. As we will note later in the paper, the actual existence, much less the precise date, of a break point in the data in the 1990s remains somewhat controversial. See Filardo (1995) for an early discussion of the productivity revival.
} 
and for the durable and non-durable components of manufacturing separately. These series are published quarterly, e.g., BLS (2000a), and are available at http://www.bls.gov/lprhome.htm.

The manufacturing labor productivity series is shown in Chart 2. The growth of labor productivity in manufacturing is typically significantly higher than that for all of nonfarm business, but exhibits a similar procyclical pattern. Manufacturing productivity growth slackened somewhat in the 1970s. Apparently, its rebound began earlier than that for all business and has been much more pronounced-measured manufacturing productivity growth in recent years has been even stronger than in the 1950s and 1960s.

A related broad measure of labor productivity produced by the BLS is for nonfinancial corporations (Chart 3). This series has gained some attention in recent years (Corrado and Slifman, 1999), in part because the data from this very large sector may be better than elsewhere. Output in the financial sector is, by definition, excluded from it, and other sectors, which are quite difficult to measure such as construction, medicine, education, and law, are smaller parts of the corporate sector than they are of the economy as a whole. Chart 3 shows that nonfinancial corporate productivity did not show as pronounced a slump in the 1970s and 1980s as did nonfarm business productivity; in the 1990s, its growth has rebounded to a faster pace than in the 1960s.

A final set of disaggregated labor productivity data are maintained by the BLS Division of Industry Productivity Studies, which now publishes labor productivity measures for over 500 3-digit and 4-digit industries, as defined by the Standard Industrial Classification (SIC) system. This program includes estimates of labor productivity series for certain manufacturing and service industries that are available at an annual frequency. Currently, the data are available through 1997 for manufacturing industries and 1998 for mining and service-related industries, and the series are updated periodically as new data become available.

Data from the Bureau of Economic Analysis (BEA) can also be used to produce labor productivity estimates, which differ in certain respects from that of BLS. BEA produces output data at roughly the two-digit SIC industries in their "gross product originating (GPO)" database, which measures each industries' contribution to gross domestic product (Lum and Moyer, 2000)). These data are available in both current and chain-weighted dollars. BEA now also makes "gross output" data available for all industries; we discuss differences between the GPO and gross output concepts below. BEA uses a different concept of labor than BLS; instead of 
hours worked their measure is full-time equivalent workers. The BEA real output data can be divided by the BEA's labor series to derive either aggregate or industry labor productivity series. ${ }^{6}$ Like the BLS industry productivity series, the BEA industry data are only available at an annual frequency, and there are considerable lags in their construction, due to the difficulties in compiling the employment data and the detailed data by industry. ${ }^{7}$

\section{(b) Total Factor Productivity}

All the series described so far relate to the productivity of labor, defined as output per hour worked or per employee. As discussed in more detail below, in order to understand the growth of labor productivity, it is sometimes helpful to look a bit more deeply at the data to the contributing factors. To this end, economists have developed sophisticated methods to measure the contributions to labor productivity from measurable factors such as changes in the educational achievement and experience of the workforce, and changes in the amount and composition of capital with which labor works.

Any remaining portion of productivity growth left unaccounted for, i.e., the amount of output growth not explained by measured input growth, is usually called "total factor productivity (TFP)." ${ }^{\prime \prime}$ Presumably, total factor productivity growth reflects phenomena such as general knowledge, the advantages of particular organizational structures or management techniques, reductions in inefficiency, and reallocations of resources to more productive uses. We return to the details of TFP calculations in the following section.

The BLS produces annual estimate of total factor productivity growth for large sectors of the economy, e.g., the private business and nonfarm business sector (BLS, 2000b). BLS also produces estimates for manufacturing and 18 component industries within manufacturing, but it does not regularly publish total factor productivity estimates for either the service sector as a whole, or for individual service industries. Gullickson and Harper (1999) provide estimates for recent periods based on unpublished BLS data.

The BLS total factor productivity series for all nonfarm business is illustrated in Chart 4. In general, broad movements in this series are similar to those in labor productivity; higher in the

\footnotetext{
${ }^{6}$ Nordhaus (2000) uses the gross product originating data in a recent productivity study, while Stiroh (2001a) uses the gross output data.

${ }^{7}$ For instance, one clearly needs a great deal of labor market information to compute the number of part-time workers who equal a full-time worker.
} 
1960s and late 1990s than in the intervening period. Other estimates are also made of total factor productivity growth. Table 1 also shows the annual estimates through 1999 from two recent studies (Jorgenson and Stiroh 2000, Oliner and Sichel, 2000), which are broadly similar to the available BLS numbers through 1998.

\section{(c) Difficulties with Sectoral and Industry Productivity}

It may be surprising that data on productivity, particularly total factor productivity, in large sectors or major industries is so scarce. The problems with compiling such data are both practical and conceptual. On a practical level, detailed sectoral or industry data on output and inputs (including labor) can be problematic; sampling problems that wash out at the aggregate level appear in full force when individual industries are examined.

The conceptual problems with examining disaggregated data are also severe. They relate primarily to the definition of "output." There are two standard concepts of output in the economics literature: value added (also called gross product originating) and gross output. Gross output equals the total value of sales and other operating receipts of an economic unit, while value added subtracts from gross output the value of goods and services purchased from other units and used in the course of production (intermediate inputs). The BLS nonfarm business sector and BEA GPO data are value added concepts, while the manufacturing total factor productivity estimates are based on a gross output concept (See Lum, Moyer, and Yuskavage (2000) for details on these definitions).

Value added is an attractive measure because it is fairly easily measured in current dollars: the current dollar value added of an economic unit is its current dollar income (payments to labor and capital), which is observable from tax data. Current dollar value added summed across all industries, therefore, has the nice property that it equals GDP when all economic sectors are included. However, value added can be difficult to measure in constant dollars, since, in principle, sales and inputs should be deflated by separate price indexes. 9 In particular,

\footnotetext{
${ }^{8}$ Another term is the "Solow Residual" in honor of Robert Solow, the economist who popularized the concept. The BLS typically refers to this concept as "multifactor productivity (MFP)." All three terms are synonymous.

${ }^{9}$ This deflation problem complicates the contention that productivity in nonfinancial corporate business is more observable than that for the overall economy. It is certainly correct that (with some lag) the income of nonfinancial corporations is measured well. However, there are surely significant problems in computing the real value of goods and services purchased by these corporations, and thus in computing their real value added and productivity. Most notably, nonfinancial corporations are major consumers of services purchased from financial firms. The problems with deriving price indexes for financial services are well-known, and recognition of these makes the nonfinancial
} 
deflation of inputs is problematic in large part since the mix of services inputs used by an economic unit can vary considerably. While BEA currently employs a "double deflation" method for all private industries to measure real value added, ${ }^{10}$ the reliability of the estimates for any one industry can affect those for many others.

Gross output per worker is closer to the ordinary notion that productivity is measured as sales per worker. Real gross output may also be easier to measure than real value added since it depends largely on deriving price indexes for observable sales. Furthermore, it may be a conceptually more valid measure for productivity analysis than value added since it will not be distorted by changes in the mix of primary and intermediate inputs. ${ }^{11}$ Care must be taken when analyzing the impact of industry or sectoral trends in gross output per worker for the economy as a whole, however, since the sales of many entities are intermediate inputs to other sectors and not part of final demand or GDP, which is a value added concept.

\section{Why is Productivity Growth Important?}

Labor productivity growth by itself is simply a statistic reported in a number of ways by a number of government agencies. Total factor productivity growth is even more abstract and much more a construct of economists. The interest in these numbers reflects the belief that they are related to a number of things that are important to economists and policymakers: overall economic growth, growth in real per capita incomes, and inflation.

\section{(a) Productivity Growth and Economic Growth}

The relationship between labor productivity growth and overall economic growth would seem to be obvious. Output growth is, by definition, the sum of the growth of labor hours plus labor productivity growth. ${ }^{12}$ Hence, higher productivity growth would appear to be associated with higher output growth. Of course, for periods as long as decades, demographic forces differ substantially, which affects the growth of labor input and aggregate output independently of productivity trends.

corporate data a bit problematic. The data for the nonfarm business sector as a whole has less of this problem, since financial firms are part of this larger sector, and the bulk of their sales are to other nonfarm businesses.

${ }^{10}$ See Lum et al. (2000) for details.

${ }^{11}$ The empirical evidence rejects the technical assumption of separability that is required for real value added to provide a valid index of production (Norsworthy and Malmquist, 1983) and Jorgenson, Gollop, and Fraumeni, 1987). Basu and Fernald (1995) show that value added data can give misleading estimates of production parameters like the degree of returns to scale.

${ }^{12}$ See Blinder (1997) and Krugman (1997) for a discussion of the usefulness of this simple relationship. 
Perhaps surprisingly, the simple link between output and productivity growth is not completely reliable at aggregate levels in the U.S data. Chart 5 plots the growth rate of real nonfarm business output and labor productivity for each decade and each half-decade from the 1960s to the 1990s. From decade to decade there is a strong consistent relationship between swings in labor productivity growth and swings in output growth. For example, output growth slowed substantially in the 1970s and 1980s as labor productivity growth slowed, while output growth improved in the 1990s as labor productivity growth rebounded.

The relationship between productivity and aggregate output growth seems somewhat looser when we move from decade to half-decade data. The strongest period for productivity growth (1960-64) is not the strongest period for output growth; the weakest period for productivity growth (1985-89) is not the weakest period for output growth. In all likelihood, this loosening occurs because there is considerable non-demographic variability in hours worked across five-year periods. Business cycle forces heavily affect the demand and supply for labor, so the resulting cyclical swings in the quantity of labor can either augment or reduce the output effects of productivity fluctuations. The strength of the business cycle varies considerably when looking across half-decades; moreover, the configuration of these forces can change from cycle to cycle. Over the course of a decade, however, business cycles tend to smooth out as does the growth of the quantity of labor. This smoothness in labor force should deepen as the time frequency lengthens, hence very long-run projections of the economy such as those produced by the Congressional Budget Office (CBO, 2001) essentially reflect demographic and productivity assumptions.

The effect of timing on the relationship between productivity growth and output growth is shown more extensively in Chart 6, which plots the correlation between the two series from 1 to 40 quarters. The correlation is quite high at 1 quarter, then falls off rapidly, is flat up to 5 years (20 quarters), and then rises. This pattern suggests that there are two types of connections between productivity growth and output growth—the long run or "demographic" relationship, and a very short-term or "cyclical" one.

The very strong short-run relationship between output and productivity suggests that it is difficult to compute the true magnitude of the late-1990s improvement in productivity. Real output growth has also strengthened recently, and it is possible that some of the improvement in productivity will disappear from the data if and when output growth slows. Robert Gordon 
(1999, 2000), for example, has argued that much of the recent productivity gains are cyclical in nature and will likely fade when the economy slows.

(b) Productivity Growth and Per-Capita Income Growth

Standard textbook economics asserts that productivity growth and the growth of real wages are equal. Quite often this proposition is stretched to make the claim that productivity growth equals the growth of real per-capita income. In reality, the relationship between productivity and income is not that tight. A standard measure of real per capita income is constant-dollar per capita disposable income, where the personal consumption expenditures deflator is used as the price measure. The correlations between this income measure and productivity growth for periods from one quarter to ten years is shown in Chart 7 . The shortterm correlation is quite weak, but grows steadily as the interval increases.

There are many reasons why the short-term correlation between productivity growth and income growth could be weak. On a conceptual level, the theoretical link between productivity and real wages strictly holds only if an economy produces one good using a constant returns to scale production technology. These requirements-especially the "one-good" assumptionhardly strictly hold for the US economy! The multiplicity of produced goods means that there will likely be a divergence between growth in the output price deflator used to compute productivity and real wages, and growth in a consumer product price series used to compute real incomes. Furthermore, there is considerable slippage between growth in wages per hour, and growth in income per capita. There's more to income growth (especially on an after-tax basis) than growth in wages or even overall compensation, and there is not a fixed relationship between hours worked and population due to fluctuations in unemployment, labor force participation, and hours worked per person.

Over the longer run, many of these slippages should lessen in importance; the differences between output and consumer prices lessen, growth in after-tax income and compensation look more alike, and growth in hours and population converge. Thus, the correlation between productivity and real income increases as the time period examined lengthens, and the adage that productivity growth is the key to income growth looks increasingly plausible.

\section{(c) Productivity Growth and Inflation}

Some macroeconomists are fond of the saying "inflation is always and everywhere a monetary phenomenon." Productivity growth is the epitome of a non-monetary phenomenon: as 
we will discuss below its two main determinants are believed to be capital formation and the evolution of technology. It's not clear that there should be any stable relation between inflation and either capital formation and technological change, so inflation and productivity could be unrelated. Nonetheless, the data appear to show linkages between productivity growth and inflation.

The correlation between productivity growth and inflation, measured by the chained price index for GDP, ${ }^{13}$ is shown for frequencies from one quarter to 10 years in Chart 8 . The onequarter correlation is negligibly small, but as the interval increases the magnitude of the relationship grows. The (negative) correlation is smaller than for output growth or real income, but it persists at a fairly stable level through the longest frequency examined. It seems to be the case that periods of higher productivity growth are periods of lower inflation.

If productivity growth is inherently a "real" phenomenon, and inflation is inherently a "monetary" phenomenon, why should there be such a relationship? One possibility is that the causation goes from inflation to productivity growth; higher inflation rates could distort the price mechanism and may be associated with reduced efficiency throughout the economy. In other words, inflation may have a negative impact on capital accumulation or technical change. Another explanation may be that periods of high productivity growth, since they are periods of relatively fast output and real income growth, are the times in which it is easier for monetary authorities to pursue anti-inflationary policies. If positive (negative) productivity surprises act as positive (negative) supply shocks, then monetary policy can be restrictive (expansive) with fewer (heightened) effects on real variables. ${ }^{14}$

For instance, it is arguable that the unexpected decline in productivity growth in the 1970s was a major factor behind the contemporaneous increase in inflation. In that decade, downward pressures on real output and income growth from reduced productivity growth complicated the environment for anti-inflationary policies. This view was concisely summed up in the 1979 Economic Report of the President, which stated "Productivity growth in 1978 showed a very marked slowdown from accustomed rates, adding substantially to inflationary pressures and raising fundamental concerns about underlying trends (Council of Economic

\footnotetext{
${ }^{13}$ The results are similar with the chained personal consumption expenditures index.

${ }^{14}$ Meyer (2000) discusses monetary policy choices in response to changes in productivity growth.
} 
Advisors, 1979, pg. 67)." Likewise, the mirror image of faster productivity trends in the late 1990s may have helped create an environment favorable to reductions in inflation.

(d) VAR Evidence on Linkages

The above interpretations of the simple correlations between productivity and output, income, and inflation in the preceding discussion are clouded by the presence of other factors that jointly influence the variables. One simple way to correct for these effects - at least for common trends - is to examine impulse response functions computed from vector autoregression (VAR) systems relating productivity growth to each of the other variables. The responses relate impulses (changes in a variable not accounted for by recent movements in itself and the other variable) in productivity growth to growth in output, real income, and inflation, as well as those relating impulses in the three latter variables to productivity growth.

These impulse responses, estimated from the three bi-variate systems, are shown in Chart 9, along with two standard error bands surrounding the point estimates. There is clearly a sharp bi-directional short-term relationship between productivity impulses and output growth, and between output impulses and productivity growth. These relationships quickly fall off and are consistent with the simple correlation between output growth and productivity growth being high at one-quarter, but weakening as longer intervals are examined. The short-term impulse response relations from productivity to real income and inflation, and from real income and inflation to productivity, are weaker in magnitude and also consistent with the simple correlations.

\section{What Factors Determine Productivity Growth?}

We next identify the factors that are believed to determine labor productivity to better understand how it evolves. We begin with a traditional "sources of growth" analysis that decomposes labor productivity growth into three primary components - capital deepening, labor quality, and total factor productivity. This approach has been used in much applied productivity work. For example, BLS (2000b) provides the official U.S. productivity history; CBO (2001) and Council of Economic Advisors (CEA, 2000) project U.S. growth; and Gordon (2000), Jorgenson and Stiroh (2000), and Oliner and Sichel (2000) examine the impact of information technology, all using this traditional growth accounting approach.

While this methodology provides valuable insights on the growth process, there are also several well-known caveats that deserve mention. Most important, this approach accurately 
quantifies the proximate sources of growth like capital accumulation and hours growth, but it cannot really identify the deeper forces that determine those variables. This requires a more fully developed model of consumer preferences, firm decisions, and policy variables. Moreover, total factor productivity growth - often interpreted as a proxy for technology - is an important force that remains exogenous to the framework and essentially unexplained. ${ }^{15}$ With these caveats in mind, we move to the details beneath a neoclassical growth accounting analysis.

\section{(a) Traditional Sources of Productivity Analysis}

We begin with an aggregate production function that relates output to the primary inputs, capital and labor, as well as the level technology available each period. Under standard assumptions that all inputs are paid their marginal product and all income is paid out to primary inputs (input exhaustion), one can mechanically derive the following relationship for labor productivity growth, $d \ln (Y / H)$ :

$$
\text { (1) } d \ln (Y / H)=v_{K} \cdot d \ln (K / H)+\left(1-v_{K}\right) \cdot(d \ln L / H)+d \ln A
$$

where $Y$ is real output, $H$ is hours worked, $v_{K}$ is capital's share of national income, $K$ is the flow of capital services, $L$ is labor input, and $A$ is total factor productivity. Jorgenson and Stiroh (2000) provide details.

Equation (1) relates labor productivity growth to three factors. The first term is capital deepening. Workers are more productive when they have more or better physical capital to with which to work. Labor productivity grows proportionately with the growth in capital per hour worked. The second is a labor quality effect that measures productivity gains as firms substitute towards workers with more skills and higher marginal products. Again, labor productivity grows in proportion to the growth in labor quality, which is difened as the growth in labor input per hour worked. The final factor is total factor productivity (TFP), a catch-all term that captures the impact of technological change, as well as increasing returns to scale, omitted variables, reallocations from low to high productivity activities, and any remaining measurement error.

We now discuss how each of these three factors can be estimated. The methodology is well established and recent applications can be found in BLS (2000b), Jorgenson and Stiroh (2000), and Oliner and Sichel (2000). While there are some differences across studies, we

\footnotetext{
${ }^{15}$ See Hulten (2000) and Stiroh (2001b) for a description of how this dissatisfaction contributed to the emergence of new growth theory.
} 
briefly review what might be considered best practice in this area. BLS (1997a) provides details on the procedure and data sources used in the BLS calculations.

\section{i) Capital Deepening}

Capital deepening reflects the increase in the amount of services from physical capital available to each worker. As firms invest and purchase new equipment and structures, the workforce becomes better equipped and is able to produce more output; hence, productivity growth rises proportionally with capital deepening. ${ }^{16}$

As can be seen from Equation (1), there are three pieces of data required to estimate the capital deepening term - capital's share of nominal income $\left(v_{K}\right)$, the flow of capital services $(K)$, and hours worked $(H)$. It is relatively easy to measure hours worked and capital's income share; the former are available directly from the BLS and the latter is available from national income data from the BEA.

The more difficult methodological question is how to properly measure the amount of capital services available for production. This topic has received considerable attention by economists, and we review what has become standard practice. ${ }^{17}$ In particular, we focus on two specific issues - how to treat individual assets whose productive characteristics are rapidly changing over time, and how to correctly aggregate different types of capital into a single number that adequately captures the productivity attributes of all component assets. Both are fundamentally questions of accurately measuring capital as a factor of production and are central to production theory.

We begin with the issue of assets that are steadily becoming more productive over time. Since firms purchase new capital goods each year through their investment in plant, equipment, and structures, the business investment data produced by the BEA is the appropriate starting point (BEA, 1998). Given information on decay and retirement, one can estimate the productive stock of capital for each distinct type of asset through the standard perpetual inventory method:

$$
\text { (2) } S_{i, t}=I_{i, t}+\left(1-\delta_{i}\right) S_{i, t-1}
$$

\footnotetext{
${ }^{16}$ The proportionality depends on capital's share of nominal income, which, under the neoclassical assumptions, equals the elasticity of output with respect to capital. Note that there is no restriction that this share remains constant over time; it varies as businesses change their input proportions and as relative prices change.

${ }^{17}$ See Jorgenson (1990) for a theoretical discussion and Hulten (2000) for a more recent review of major issues.
} 
where $S_{i, t}$ is capital stock, $I_{i, t}$ is investment, and $\delta_{i}$ is the physical depreciation rate for asset $i$ at time $t$.

The perpetual inventory method gives the familiar interpretation of the capital stock as a weighted sum of past investments, with weights determined by the efficiency profile of capital of different ages. ${ }^{18}$ Implicit in this approach is the assumption that investments in a particular asset from different years are perfect substitutes for one another. Given the enormous quality change in certain assets like computers, this may seem unreasonable at first glance. This problem is well-known, however, and both BEA and BLS spend considerable resources to develop the appropriate data to deal with it.

BEA now employs "constant-quality" prices deflators for many assets with rapid quality change over time. In essence, these deflators measure the price of a bundle of productive characteristics over time rather than the price of a particular unit. This translates quality improvements across different vintages of investment into increases in the quantity of homogeneous "efficiency units." As a concrete example, consider how real computer investment is measured when current models are much more powerful than earlier ones, e.g., faster processors, larger hard-drives, more memory, etc. The observed purchased price of a computer system has not changed very much, so large improvements in performance imply the price of these productive characteristics has fallen. As a consequence, the official price index for computers has fallen rapidly, nearly $30 \%$ per year since 1995, while the real quantity of investment has exploded. Thus, correct deflation of nominal investment accounts for quality improvements in a particular asset over time. ${ }^{19}$

Given the constant-quality deflators and depreciation rates, Equation (2) describes the evolution of the productive stock of capital, measured in consistently defined efficiency units, for each asset. Not all investment goods and capital assets are the same, however, and one must carefully account for this heterogeneity to construct an appropriate measure of aggregate capital input used by an industry or economy. Information technology assets have high marginal

\footnotetext{
${ }^{18}$ An efficiency profile shows the effective amount of investment that remains as an assets ages and loses productive capacity due to decay and retirement. Equation 2 assumes a geometric decline so that a piece of one-year old capital is $(1-\delta) \%$ as productive as a new piece, a piece of two-year old capital is $(1-\delta)^{2} \%$ productive as a new piece, etc.
} 
products and relatively short service lives, for example, which makes them quite different from long-lived assets like non-residential structures.

To account for these differences, most recent studies incorporate a "capital services" methodology. This approach, developed by Jorgenson and Griliches (1967), creates an aggregate measure of capital services by using each assets' marginal product to determine the appropriate weight. Assets with higher marginal products receive larger weights. The main practical concern is how to estimate the marginal product for each type of capital needed for weights, and for this we can turn to economic theory for guidance.

Consider the firm's investment decision where it is choosing between buying a productive asset or some alternative investment opportunity. To be an equilibrium, the firm should be just indifferent between two alternatives: investing the money $\left(P_{i, t-1}\right)$ and earning a nominal rate of return, or buying the piece of capital with the same amount of dollars, collecting a rental fee (or equivalently, profiting from the use of the asset for a period), and then selling the depreciated asset at next period's price $\left(P_{i, t}\right)$. This implies the following equilibrium condition:

$$
\text { (3) }\left(1+i_{t}\right) P_{i, t-1}=c_{i, t}+\left(1-\delta_{i}\right) P_{i, t}
$$

where $i_{t}$ is the nominal interest rate, $P_{i, t}$ is the acquisition price, and $c_{i, t}$ is the rental or service price for asset $i$ at time $t$. Rearranging yields the familiar "cost of capital" or "user cost" equation:

$$
\text { (4) } c_{i, t}=\left(i_{t}-\pi_{i, t}\right) P_{i, t-1}+\delta_{i} P_{i, t}
$$

where $\pi_{i, t}$ is the percent change in the acquisition price. ${ }^{20}$

Equation (4) can be evaluated for each asset to produce an estimate of an asset-specific cost of capital, $c_{i, t}$, which equals the value of the marginal product of the asset under the neoclassical assumptions. To better understand the economics of the cost of capital equation, again consider the case of computers. Measured in constant-quality efficiency units, computer prices have fallen rapidly $\left(\pi_{i, t}\right.$ is large and negative) and computers obsolesce quickly ( $\delta_{i}$ is large and positive), so $c_{i, t}$ is large and positive. Computers must have a large service price and

\footnotetext{
${ }^{19}$ These constant-quality indices are often estimated from hedonic regressions. See Wasshausen (2000) for details on computer prices, Parker and Grimm (2000) for estimates of software prices, and Triplett (1986) for a discussion of hedonic theory.

${ }^{20}$ As shown in Hall and Jorgenson (1967), tax factors also play an important role in determining the cost of capital. We omit this issue for simplicity.
} 
correspondingly high marginal product value to compensate for large capital losses and rapid obsolescence.

These service price estimates directly affect the aggregate measure of capital since they serve as aggregation weights for different types of capital. ${ }^{21}$ A comparison between the growth of capital services, which uses the cost of capital as the weight for each asset, and the growth of the capital stock, which uses the acquisition price as the weight is shown in Chart 10. The index of capital services grows much faster (4.2\% per year) than the index of capital stock (3.2\%) for the full period 1959 to 1998 . This divergence is particularly strong in the later periods and represents the substitutions towards short-lived assets, like computers and other information technology, with relatively high marginal products. Failure to account for the relatively high marginal product would understate the growth in productive capital services.

ii) Labor Quality

Growth in labor quality captures the increase in labor input from a changing mix of workers. As the workforce evolves and workers with different skills and marginal products are employed at different rates, this change in composition directly affects how much output can be produced from a given quantity of worker hours. For example, as relative wages changes, firms substitute between different types of workers and this changes the average productivity of the workforce. This composition effect is often referred to as a change in labor quality.

To be more precise, recall that Equation (1) defines labor quality growth as the difference between growth in aggregate labor input $(\mathrm{L})$ and aggregate labor hours $(\mathrm{H})$. Again, estimates of labor hours are relatively easy to obtain by summing the hours worked of all types of workers and computing the growth rate. In this calculation, all types of workers are essentially treated the same and receive identical weights.

A more difficult task is to construct an estimate of aggregate labor input that accounts for the changing composition of workers. Rather than simply summing hours of all types of worker, estimates of aggregate labor input employ weights equal to marginal products. Like the estimates of capital services, it is appropriate to recognize the heterogeneity across different types of workers that provides a more accurate measure of labor input used in production.

\footnotetext{
${ }^{21}$ For example, the Tornqvist index weights growth rates of different types of capital using service price shares to estimate the growth of aggregate capital input.
} 
Following economic theory, relative marginal products can be inferred from observed wage differentials across classes of workers, i.e., workers cross-classified by age, education, sex, industry, etc. This can be done econometrically (BLS (1997b)), or by calculating the relative wages of different types of workers directly (Ho and Jorgenson (1999)). These two approaches are conceptually similar, and it is really a data decision about which is preferred. The common assumption is that relative wages capture differences in the workers' productivity and that the quality of a specific type of worker is constant over time.

Chart 11 plots the growth rate of labor input $(L)$ and hours worked $(H)$ from 1959-98. As discussed above the difference in growth rates between these two series reflects changes in the composition of the workforce, often referred to as labor quality change. For the full period 195998 , growth in labor input exceeded growth in hours worked (2.1\% vs. $1.6 \%)$, implying steady growth in labor quality due to demographic factors and compositional changes in the workforce.

iii) Total Factor Productivity

The third factor identified in the traditional sources of growth analysis is total factor productivity (TFP) growth. Also known as the "Solow residual" in honor of Robert Solow, the Nobel laureate who first integrated the idea of technical change with the production function and national accounting data, TFP growth represents the ability to produce more output from the same inputs. Conceptually, this can be thought of as a shift in the production function. TFP is often viewed as a measure of technological change, but it also reflects additional factors like economies of scale, resource reallocations, and measurement error, as well as the growth in disembodied technology.

At this point it is worthwhile to be very clear how TFP growth is actually estimated. Under the assumptions used to derive Equation (1), TFP growth, $d \ln A$, is defined as

$$
\text { (5) } d \ln A \equiv d \ln Y-v_{K} d \ln K-\left(1-v_{K}\right) d \ln L
$$

Thus, TFP growth is not observed at all; rather, it is calculated as a residual as the output growth not explained by weighted input growth. This is consistent with the interpretation of TFP growth as a shift in the production function, but it is also somewhat unsatisfying since, as a practical matter, TFP growth is a catch-all term that captures the impact of all growth factors not explicitly measured by the economist. Investment in unmeasured inputs like research and development or any mismeasured capital and labor inputs, for example, effects the measured TFP residual. 
Moreover, the TFP estimate derived from this approach gives a valid estimate of technical change only under the assumptions of competitive markets and input exhaustion. As pointed out by Hall (1988), Hulten (2000), and others, if these assumptions fail, the traditional TFP residual diverges from what the economist is really trying to measure. Basu and Fernald (1997), however, argue that even if not a pure indicator of technical change, measured TFP is a valuable welfare indicator. Finally, even if correctly measured, this approach can only quantify how the rate of technical change fluctuates; it cannot explain why it changes. TFP growth is entirely exogenous to this framework, and thus without an economic explanation in this standard neoclassical model.

\section{(b) Recent Estimates}

With this measurement framework in hand, we review how each factor contributed to the resurgence of U.S. labor productivity growth. As discussed earlier, there has been a tremendous revival in U.S. labor productivity growth. After growing 1.5\% per year from 1973 to 1995 , annual U.S. business sector productivity jumped to 2.7\% per year from 1995 to 1999 (BLS, 2000a). To move beneath this number and understand the proximate sources of acceleration, we discuss the decomposition results reported by BLS (2000b), Jorgenson and Stiroh (2000) and Oliner and Sichel (2000) and examine each of the three factors identified by Equation (1).

Table 2 reports the growth decomposition for 1973-95 and 1995-99 from the two academic studies and 1973-95 and 1995-98 for the BLS study. Given that the studies use the same basic methodology and data sources, it is not surprising that they reach similar conclusions. $^{22}$ Since 1995, output growth has accelerated by nearly two percentage points, due largely to faster labor productivity growth (up about 1.2 percentage points), but also due somewhat to faster growth in hours worked (up about 0.6 percentage points). It is the acceleration of labor productivity that is most striking and has the most important implications for macroeconomists.

Moving beneath the labor productivity estimates, we find that these gains primarily reflect more rapid capital deepening and faster TFP growth. Both Jorgenson and Stiroh (2000) and Oliner and Sichel (2000) emphasize that accelerated capital deepening is due in large part to

\footnotetext{
${ }^{22}$ There are differences, of course. This largely reflects the broader output concept used by Jorgenson and Stiroh (2000), differences in estimates of self-employed workers, and differences in the construction of capital stocks. See Oliner and Sichel (2000) for a detailed comparison.
} 
the recent boom in high-tech investment, particularly computer hardware. As the relative price declines of these assets accelerated in the late 1990s, firms responded with massive investment and capital accumulation. Similarly, both studies identify rapid technical progress in the hightech industries as a source of accelerating aggregate TFP growth. As high-tech firms become increasingly able to produce more advanced hardware, semiconductors, and software, their productivity rises and drives aggregate TFP upward. As a final point, there is little change in the growth of labor quality in the late 1990s. This is consistent with the notion of a very tight labor market as relatively low-skill workers are drawn into the labor pool.

These traditional sources of growth studies show that the U.S. economy in the late 1990s appears quite different from the prior two decades. Technical progress, in particular, seems to have accelerated in recent years, driving both TFP growth and inducing massive investment in high-tech assets. As a readily acknowledged caveat, however, this type of analysis cannot explain why technical progress accelerated in the high-tech industries, which remains an important issue for economists interested in the performance and organizational structure of these industries. Nonetheless, this analysis is quite useful. By identifying the proximate sources of productivity growth, analysts can better understand the growth process and can more effectively address policy questions of how to stimulate growth.

\section{Important Productivity Questions}

We now apply the data and concepts described previously to some current productivity issues discussed in the academic, policymaking, and forecasting communities. All of these issues are unresolved, but systematic discussion is useful to understand the way answers may be obtained in the future.

(a) The Productivity Revival: Cyclical or Structural?

U.S. productivity growth clearly has a major cyclical component. Overall economic growth strengthened substantially in the latter half of the 1990 as the U.S. economy appeared to be growing faster than its sustainable trend. It has been argued, especially in Robert Gordon (1999, 2000), that much of the rebound in productivity growth in recent years is a reflection of the strengthening of aggregate demand, rather than a fundamental improvement in the medium or longer-term productivity trend. This cyclical argument has several facets.

The neoclassical growth accounting results presented in Table 2 suggest that much of the

recent improvement in labor productivity growth is due to faster capital deepening and an 
upswing in TFP growth. Capital deepening itself has a normal cyclical component since investment is highly cyclical, so the recent capital deepening may be less a factor leading to faster productivity growth and more a consequence of faster economic growth.

TFP growth is also highly cyclical (Chart 4). The cyclical component of TFP growth likely reflects more intensive use of capital and labor resources by firms when demand increases. In principle, neoclassical growth accounting could pick up more intensive use of existing resources, but in practice such swings are often chalked up to fluctuations in TFP. ${ }^{23}$ Thus, the ability of the neoclassical framework to account for the recent increase in labor productivity growth need not be inconsistent with the claim that much of the increase is inherently cyclical, and may vanish when overall growth cools off and the current investment boom ends.

Finally, the estimation framework discussed in the previous section was developed to address the sources of growth over longer-terms. Over shorter time periods, the quality of the data becomes an issue (especially when dealing with the recent past, when much of the data is subject to major revision), and the basic assumptions used to derive the estimates may be questioned. Most notably, the estimates of capital services are derived assuming that output is produced using a constant-returns-to-scale technology, and that markets for capital goods and financial instruments are in full equilibrium, meaning that relative prices and financial returns provide information about user costs in a straightforward manner. These assumptions may be reasonable on average for long periods, but their relevance for short periods (and in this context five years may be a short period) can be questioned and therefore introduce additional measurement error.

Fundamentally, then, we can not dismiss the proposition that cyclical forces, rather than true improvements in the underlying trend, explain the recent improvement in productivity. This issue can only be resolved by time. Obviously, if the business cycle swings in a downward direction, the behavior of productivity will allow us to determine the importance of cyclical forces in the post-1995 improvement. If output growth stays strong, it will be reasonable to believe that cyclical forces behind the recent labor productivity and TFP growth will fade, so that capital deepening and TFP growth can be considered a force leading to, rather than resulting from, faster productivity growth. Hence, if overall growth stays strong, continued strong productivity growth should ultimately be chalked up to an improved trend. 


\section{(b) Is Higher Productivity Growth Merely a High-Tech Phenomenon?}

The official BLS data shows that the recent strengthening of productivity growth is most evident in manufacturing, and within manufacturing it is most evident within the durable goods sector. High-tech capital—for instance, computers, semiconductors, and communication equipment-is produced within this sector. The annual BEA data suggest that the fastest growth in productivity in recent years (measured as gross output per full-time equivalent worker) has been in the two-digit industries that produce these high-tech items. The quality-adjusted prices of these goods have plunged in recent years, which is another sign that productivity growth may be unusually rapid in these industries.

In contrast, improvements in productivity in other sectors have been more modest. These developments raise two issues. First, can we really believe that the productivity improvement is so narrowly based? Second, is there a qualitative difference between a productivity swing confined to a few industries and one more broadly-based?

In our discussion of the neoclassical accounting of productivity trends we noted that it is perfectly plausible to assume that the productivity revival is so unbalanced. In this framework, the high-tech industries are experiencing a major boom in TFP growth, enabling them to supply their products to the economy at much lower prices. The cheaper cost of these capital goods has allowed acceleration in capital deepening elsewhere, and induced a higher rate of labor productivity growth. The issue is really why TFP gains are so narrowly focused.

This question is, almost by construction, unresolvable in the neoclassical framework, where TFP is derived as a residual as the growth that can't be attributed to observed factors. In the case of high-tech industries it appears that true technological change is driving TFP as these industries are able to continuously produce better outputs at lower prices. As a practical matter, however, the attribution of TFP growth to particular industries is fraught with potential errors since it requires fairly detailed data on the inter-industry pattern of intermediate input trade and resource utilization. Moreover, it may be too soon to make sweeping conclusions about recent trends in industry TFP growth; revised data may show higher recent growth in some industries and lower in others.

Industry detail on productivity growth, however, may be less important in weighing the benefits of faster productivity growth. Faster labor productivity growth, no matter in what

\footnotetext{
${ }^{23}$ See Fernald and Basu (1999) for a discussion of the difficulties of measuring unobserved utilization rates.
} 
industry it occurs, allows the existing workforce to produce more output in the aggregate. Faster TFP growth, no matter in what industry it occurs, allows the existing workforce and capital stock to produce more output in the aggregate. Thus, if one is more interested in the growth of aggregate output and less interested in the distribution of that growth, e.g., a fiscal policy planner who needs to forecast future tax revenue, then breadth of productivity gains may be less important. Of course, for other purposes, like analysis of real wages and income distribution, this question may be quite important.

\section{(c) Why is Productivity Growth So Slow in the Service Sector?}

Productivity growth is disproportionately rapid in manufacturing and in the nonfinancial corporate sector, which suggests that productivity growth is disproportionately slow in the service sector. Corrado and Slifman (1999), for example, report that manufacturing labor productivity grew 3.0\% per year from 1989 to 1997, while service sector productivity declined 0.9\% per year. Similarly, Gullickson and Harper (1999) estimate that total factor productivity in services rose only $0.1 \%$ per year from 1977 to 1992 . This contrasts with the perception of important advances in production and distribution in these services sectors. In addition, there has also been considerable high-tech capital deepening e.g., Triplett (1999) and Stiroh (1998) show that the majority of computer capital is in service-related industries.

Why, then, are the productivity measures so low? One potential explanation is measurement error. It is reasonable to believe that there are major problems measuring the output of many service industries, and technological advances may have exacerbated these problems. This issue has been raised by the BLS itself, e.g., Dean (1999) and Gullickson and Harper (1999), as well as Diewert and Fox (1999), and remains an important research area for improving the national accounts.

For example, technology enables providers of financial and health services to customize their offerings to individuals or firms. Such specialization makes it extremely difficult to measure price indexes for those industries, this erodes the value of the published real output and productivity measures. The slow pace of productivity growth in these and some other service sectors has led to widespread suspicion that price inflation is overstated in these areas.

Few observers would doubt the likelihood that price inflation in large parts of the service sector is overstated, and therefore productivity growth is understated. The analytical significance of price overstatement in the service sector, however, depends upon its size relative to price 
overstatement elsewhere in the economy, and any change in such overstatement over time. Differing degrees of price overstatement across sectors will mean that the published data on the distribution of productivity growth will be misleading, which could hamper the design of effective policies to encourage true productivity growth. Furthermore, since the service sector has been growing relative to the rest of the economy over time, a relatively large price overstatement means a progressively larger understatement of true aggregate productivity growth; Griliches (1994) made this point in the context of discussing the growing share of "hard-to-measure" sectors. Sichel (1997), however, shows that even the growing share of the service sector is not enough to substantially raise measurement errors for the aggregate economy.

A worsening of measurement problems and an increase in the overstatement in inflation in the service sector could compound this problem, but the evidence is limited that any overstatement of service sector inflation is growing over time. Steindel (1999) discussed the quantitative consequences for aggregate productivity growth of progressively growing overstatement of service sector inflation. He found that, unless the problem is very severe (for instance, the relative overstatement of inflation in the service sector has recently increased by more than 2 percentage points a year), our basic assessment of longer term aggregate productivity trends through the mid-1990s would likely remain intact. However, if there is no improvement in the relative overstatement of service sector inflation, the understatement of aggregate productivity growth will worsen over time.

It might be surprising, given the size of the service sector, that service inflation overstatement doesn't look like it creates a major distortion of the aggregate productivity data. When we look at the details of the data, though, we find that the service sector share of final product sales is considerably smaller than its share of say, employment. Much of the service sector is devoted to providing inputs to goods production (think of finance), and another large share is involved in fairly straightforward activities such as transportation and power supply, where problems in pricing output are probably not that large. As pointed out by Baily and Gordon (1988), only a small portion of final product in the private sector involves output of industries, such as finance and health care, where it is plausible to argue that new technologies could have increased inflation overstatement.

It appears that the problem of limited growth of service sector productivity, if it actually is simply a data problem, involves mainly a distortion of the pattern of productivity growth 
across industries. It is possible that too high a fraction of productivity growth is being attributed to goods production, and too little to the service industries, and that advances in informationprocessing technology are increasing this problem.

\section{(d) What is Sustainable Productivity Growth?}

The recent experience with labor productivity growth projections shows this to be a very difficult question. Consider the evolution of the labor productivity projections produced by the $\mathrm{CBO}$, which is considered by some to reflect state-of-the-art methodologies. As recently as 1998, CBO (1998) forecast potential labor productivity for the nonfarm business sector to grow 1.7\% per year through 2008, slighly slower than the 1.9\% average for 1949-97. As the U.S. economy continued to outperform forecasts in recent years, CBO's projections steadily evolved. CBO (1999) forecast $2.0 \%$ potential labor productivity growth for 1998-2009, while the forecast in CBO (2000a) rose to $2.3 \%$. In the most recent forecase, CBO (2001) project $2.7 \%$ labor productivity growth for the nonfarm business sector over the next decade. Clearly, estimating sustainable productivity growth is not an easy task.

The decomposition of improved labor productivity growth into the component due to capital deepening and TFP growth lets us begin to answer this question. ${ }^{24}$ In some sense, TFP growth can not be forecast precisely because it is a residual; if we knew the forces that can be used to forecast it, we might be able to account for it in the neoclassical framework. However, given the record of the last 40 years, reasonable bounds on trend TFP growth look to be zero (the trend in the 1980s) to over 1 percent per year (the trend in the 1960s and late 1990s). CBO (2001) estimates TFP growth in the nonfarm business sector to average 1.5\% over the next decade, which reflects the more recent trends.

The effects of capital deepening would, superficially, appear to be easier to forecast. In the traditional Solow model, capital deepening raises the level of productivity, not its long-run trend growth rate. The rate of technical progress (TFP growth) is viewed as independent of capital deepening, and capital deepening can not increase indefinitely, since larger and larger shares of output will be absorbed maintaining the ever-expanding capital stock, ultimately leaving no resources to consumption. In this view, the impact of capital deepening on productivity growth will ultimately fade to zero. 
More recent thinking in the "new growth" literature is less pessimistic. In some new growth models, the growth of technical progress depends directly on the capital-labor ratio. ${ }^{25}$ Even in the traditional view, the transition to the higher productivity level will yield a lengthy period of higher productivity growth rates, and reallocation of capital across industries could yield higher aggregate productivity for some time. Finally, the budget constraint limiting the growth possibilities of capital deepening in the neoclassical model is much less binding in the current environment. The budget constraint involves an ever-increasing share of nominal output being spent on replacements for the swollen capital stock, leaving few resources for other activities. ${ }^{26}$

However, we are in a situation where the price of investment goods is falling, meaning that the higher levels of real investment spending necessary to maintain and expand the higher capital stock can be obtained with minimal increases in nominal investment spending (Macroeconomic Advisors, 1999). Thus, it appears that the contribution of capital deepening to productivity growth will be sustainable for years to come, as long as the relative price of investment goods continues to fall. While this does not lead to a balanced growth equilibrium, it may be an appropriate representation of the current economic forces. Moreover, Jorgenson and Stiroh (2000) suggest that the official price data may understate the true quality gains in computer software and telecommunications equipment, which would lead to an overstatement of true inflation, and an understatement of true capital deepening and output growth. These price concerns, however, are less important for fiscal policy analysis where nominal output growth is the more relevant factor for future budgetary considerations.

In sum, a continuation of the post-1995 trend of labor productivity growth of $2.5 \%$ per year for some years into the future, perhaps a decade, seems to be a defensible estimate of the sustainable trend growth rate. However, as the experience of the 1970s and the late 1990s suggests, forecasts of productivity can easily be wrong.

\footnotetext{
${ }^{24} \mathrm{We}$ do not dwell on labor quality projections because these are relatively straightforward based on demographic assumptions.

${ }^{25}$ See Stiroh (2001b) for a review of several "new growth" models that have this feature.

${ }^{26}$ The deterioration of the Warsaw Pact nations in the 1980s may be an almost textbook case of such a situation. An extraordinary pace of capital deepening in these nations after World War II resulted, first, in a period of rapid growth, followed by stagnation and a collapse in living standards as more and more of their output was devoted to maintaining the swollen capital stocks. Of course, nonmarket allocations of resources and high levels of military spending in these nations exacerbated the problems.
} 


\section{Conclusions}

Productivity growth is clearly a fundamental measure of economic health and all of the major measures of aggregate labor and total factor productivity have recently shown improvements after long spells of sluggishness. If this improved performance continues, strong overall performance of real growth and low inflation may be sustained, although the short-run linkage of productivity to real income (and to output, after the very shortest period) is not as tight as some might expect.

Examination of the sources of productivity growth suggests that a major source of the better aggregate performance has been the remarkable surge of the high-technology sector. Faster productivity growth in this rapidly growing sector has directly added to aggregate growth and the massive wave of investment in high-technology capital by other sectors has been equally important. Improved productivity growth has not been solely a high-tech phenomenon, but hightechnology is clearly the most prominent factor.

The increased difficulty of measuring economic activity in a period of rapid technological change may have aggravated chronic problems in measuring productivity growth in the service sector. It is doubtful, though, that the worsening of such problems has gravely distorted the aggregate data, in part because so much of the product of the service sector is sold as inputs to other businesses, rather than to final consumers.

Finally, it is possible that recent productivity growth has been swelled by the strength of aggregate activity and thus the strong recent productivity numbers may now be above their underlying long-run trend. The longer productivity growth stays strong, however, the less weight should be placed on cyclical forces and the more optimistic we can be about improvements in the underlying, longer-term trends. 


\section{References}

Baily, Martin Neil and Robert J. Gordon (1988), "The Productivity Slowdown, Measurement Issues, and the Explosion of Computer Power," Brookings Papers on Economic Activity, 2, 347-420.

Basu, Susanto and John G. Fernald, "Are Apparent Productive Spillovers a Figment of Specification Error?” Journal of Monetary Economics 36, 165-188, 1995.

(1997), "Aggregate Productivity and Aggregate Technology," International Finance Discussion Paper \#593, Federal Reserve Board.

Blinder, Alan S. (1997), "The Speed Limit: Fact and Fancy in the Growth Debate," The American Prospect, No. 34, September-October, pp. 57-62.

Bureau of Economic Analysis, Fixed Reproducible Tangible Wealth of the United States, 192596, NCN-0136, May 1998.

Bureau of Labor Statistics (1997a), BLS Handbook of Methods, April, Washington, DC: Government Printing Office.

Bureau of Labor Statistics (1997b), "Changes in the Composition of Labor for BLS Multifactor Productivity Measures, 1997," http://www.bls.gov/mprlabor.htm. (1999), “Multifactor Productivity Trends, 1997,” USDL 99-36, February 11. (2000a), "Productivity and Costs - Second Quarter 2000," USDL 00-225, August 8. (2000b), “Multifactor Productivity Trends, 1998," USDL 00-267, September 21.

Congressional Budget Office (1998), The Economic and Budget Outlook: An Update, August, Washington DC: U.S. Government Printing Office.

(1999), The Economic and Budget Outlook: An Update, July 1, Washington DC: U.S. Government Printing Office.

(2000a), The Budget and Economic Outlook: Fiscal Years 2001-2010, January, Washington DC: U.S. Government Printing Office.

(2000b), The Budget and Economic Outlook: An Update, July, Washington DC: U.S. Government Printing Office.

(2001), The Budget and Economic Outlook: Fiscal Years 2002-2011, January, Washington DC: U.S. Government Printing Office.

Corrado, Carol and Lawrence Slifman (1999), "Decomposition of Productivity and Unit Costs," American Economic Review, Papers and Proceedings, Vol. 89, No. 2, May 1999, 328332.

Council of Economic Advisors (1979), The Annual Report of the Council of Economic Advisors, Washington, DC: U.S. Government Printing Office.

(2000), The Annual Report of the Council of Economic Advisors, Washington, DC: U.S. Government Printing Office.

Dean, Edward R., "The Accuracy of the BLS Productivity Measures," Monthly Labor Review, February 1999, 24-34. 
Diewert, Erwin and Kevin Fox. "Can Measurement Error Explain the Productivity Paradox?" Canadian Journal of Economics, 32(2), April 1999, 251-280.

Fernald, John G. and Susanto Basu (1999), "Why is Productivity Procyclical? Why Do We Care?” International Finance Discussion Paper \#638, Federal Reserve Board, June.

Filardo, Andrew J. (1995), "Has the Productivity Trend Steepened in the 1990s?," Economic Review, Fourth Quarter, 41-59.

Gordon, Robert J. (1999), "Has the New Economy Rendered the Productivity Slowdown Obsolete?," Northwestern University, manuscript. (2000), "Does the 'New Economy' Measure Up to the Great Inventions of the Past," Journal of Economic Perspectives, Vol. 14, No. 4, Fall, 49-74.

Griliches, Zvi (1994), "Productivity, R\&D, and the Data Constraint," American Economic Review, 84(1), March, 1-23.

Gullickson, William and Michael J. Harper, "Possible Measurement Bias in Aggregate Productivity Growth," Monthly Labor Review, February 1999, 47-67.

Hall, Robert E. (1988), "The Relation Between Price and Marginal Cost in U.S. Industry," Journal of Political Economy, Vol. 96, October, 921-947.

Hall, Robert E. and Dale W. Jorgenson (1967), “Tax Policy and Investment Behavior,” American Economic Review, Vol. 57, 391-414.

Ho, Mun Sing and Dale W. Jorgenson, “The Quality of the U.S. Workforce, 1948-95," Harvard University, manuscript, 1999.

Hulten, Charles R. (2000), “Total Factor Productivity: A Short Biography," NBER Working Paper \#7471, January.

Jorgenson, Dale W. (1990), "Productivity and Economic Growth," in eds Ernst R. Berndt and Jack E. Triplett, Fifty Years of Economic Measurement, Chicago, IL: University of Chicago Press.

Jorgenson, Dale W., Frank M. Gollop, and Barbara M. Fraumeni (1987), Productivity and U.S. Economic Growth, Cambridge, MA: Harvard University Press.

Jorgenson, Dale W. and Zvi Griliches, "The Explanation of Productivity Change," Review of Economic Studies, Vol. 34, No. 3, July 1967, 249-283.

Jorgenson, Dale W. and Kevin J. Stiroh (2000), "Raising the Speed Limit: U.S. Economic Growth in the Information Age," Brookings Papers on Economic Activity 1, 125-211.

Krugman, Paul (1997), "How Fast Can the U.S. Economy Grow?" Harvard Business Review, Vol. 75, No. 4, July-August, 123-129.

Lum, Sherlene K.S. and Brian C. Moyer (2000), “Gross Domestic Product by Industry for 199799," Survey of Current Business, December 24-35.

Lum, Sherlene K. S., Brian C. Moyer, and Robert E. Yuskavage (2000), "Improved Estimates of Gross Product by Industry for 1947-98," Survey of Current Business, June, 25-54. 
Meyer, Laurence H., 2000, "The Economic Outlook and the Challenges Facing Monetary Policy," Remarks at the Century Club Breakfast Series, Washington University, October 19.

Nordhaus, William D, 2000, "Productivity Growth and the New Economy." Mimeo, Yale University, November 20.

Norsworthy, J. Randolph and David Malmquist (1983), "Input Measurement and Productivity Growth in Japanese and U.S. Manufacturing," American Economic Review, Vol. 73, No. 5, December 947-967.

Oliner, Stephen D. and Daniel E. Sichel (2000), "The Resurgence of Growth in the Later 1990s: Is Information Technology the Story," Journal of Economic Perspectives, Vol. 14, No. 4, Fall, 3-22.

Parker, Robert and Bruce Grimm. (2000). "Software Prices and Real Output: Recent Developments at the Bureau of Economic Analysis." Bureau of Economic Analysis. April 7. http://www.bea.doc.gov/bea/papers.htm

Sichel, Daniel E. (1997). "The Productivity Slowdown: Is A Growing Unmeasurable Sector the Culprit?" Review of Economics and Statistics,367-370.

Steindel, Charles (1999), "The Impact of Reduced Inflation Estimates on Real Output and Productivity Growth," Current Issues in Economics and Finance, Vol. 5, No. 9, June.

Stiroh, Kevin J. (1998), “Computers, Productivity, and Input Substitution,” Economic Inquiry, Vol. XXXVI, No. 2, April, 175-191.

(2001a), "Information Technology and the U.S. Productivity Revival: What Do the Industry Data Say?" Federal Reserve Bank of New York Staff Report, No. 115, January 2001.

(2001b), “What Drives Productivity Growth?” Economic Policy Review, Federal Reserve Bank of New York, Vol. 7, No. 1, March, 37-60.

Triplett, Jack E. (1986), “The Economic Interpretation of Hedonic Methods," Survey of Current Business, 86, January 36-40.

, "Economic Statistics, the New Economy, and the Productivity Slowdown," Business Economics, Vol. XXXIV, No. 2, April 1999,13-17.

Wasshausen, Dave. (2000). "Computer Prices in the National Accounts." Bureau of Economic Analysis. April.

Wolff, Edward N. (1996), "The Productivity Slowdown: The Culprit at Last? Follow-Up on Hulten and Wolff," American Economic Review, Vol. 86, No. 5, 1239-1252. 


\section{NONFARM PRODUCTIVITY GROWTH}

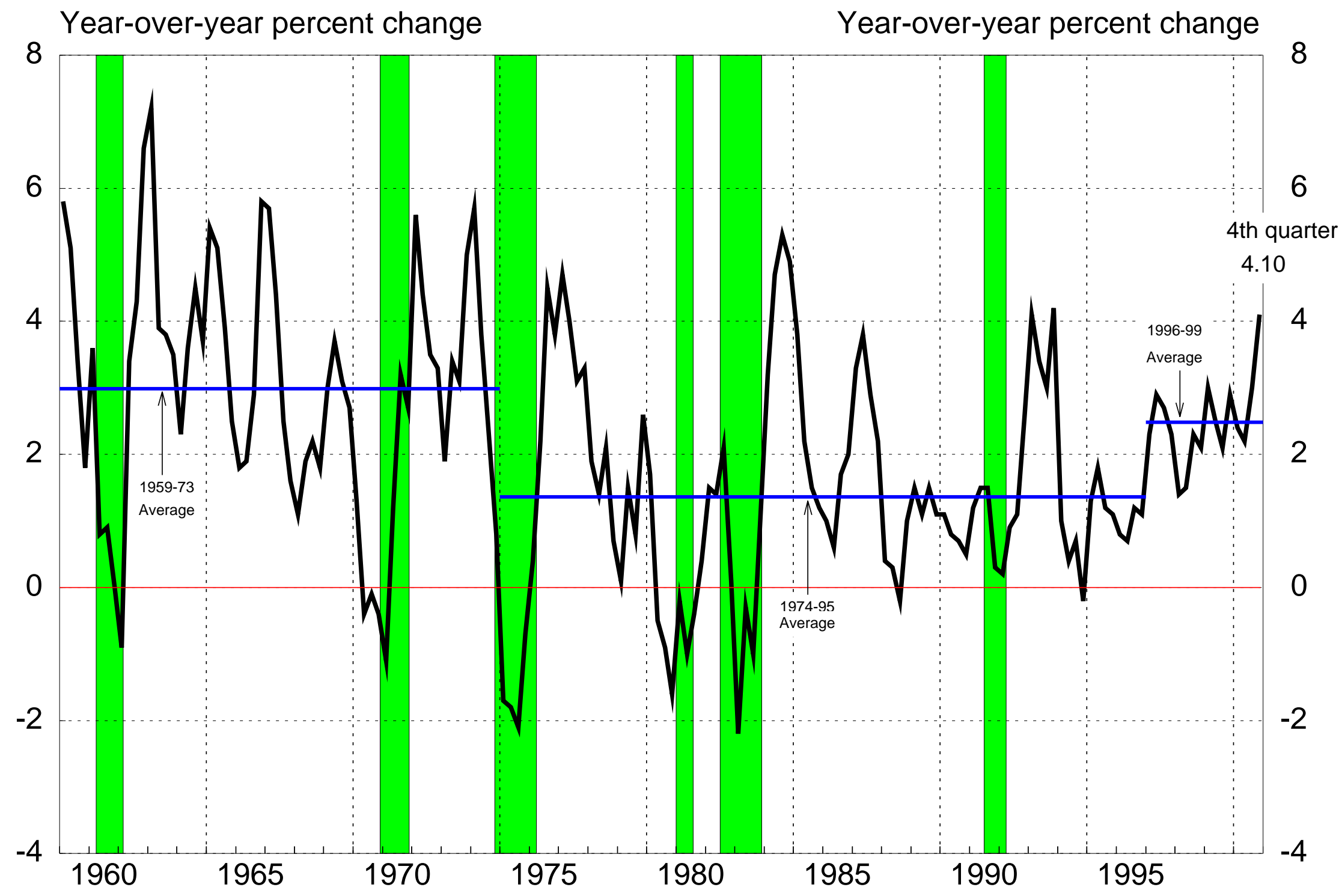




\section{MANUFACTURING PRODUCTIVITY GROWTH}

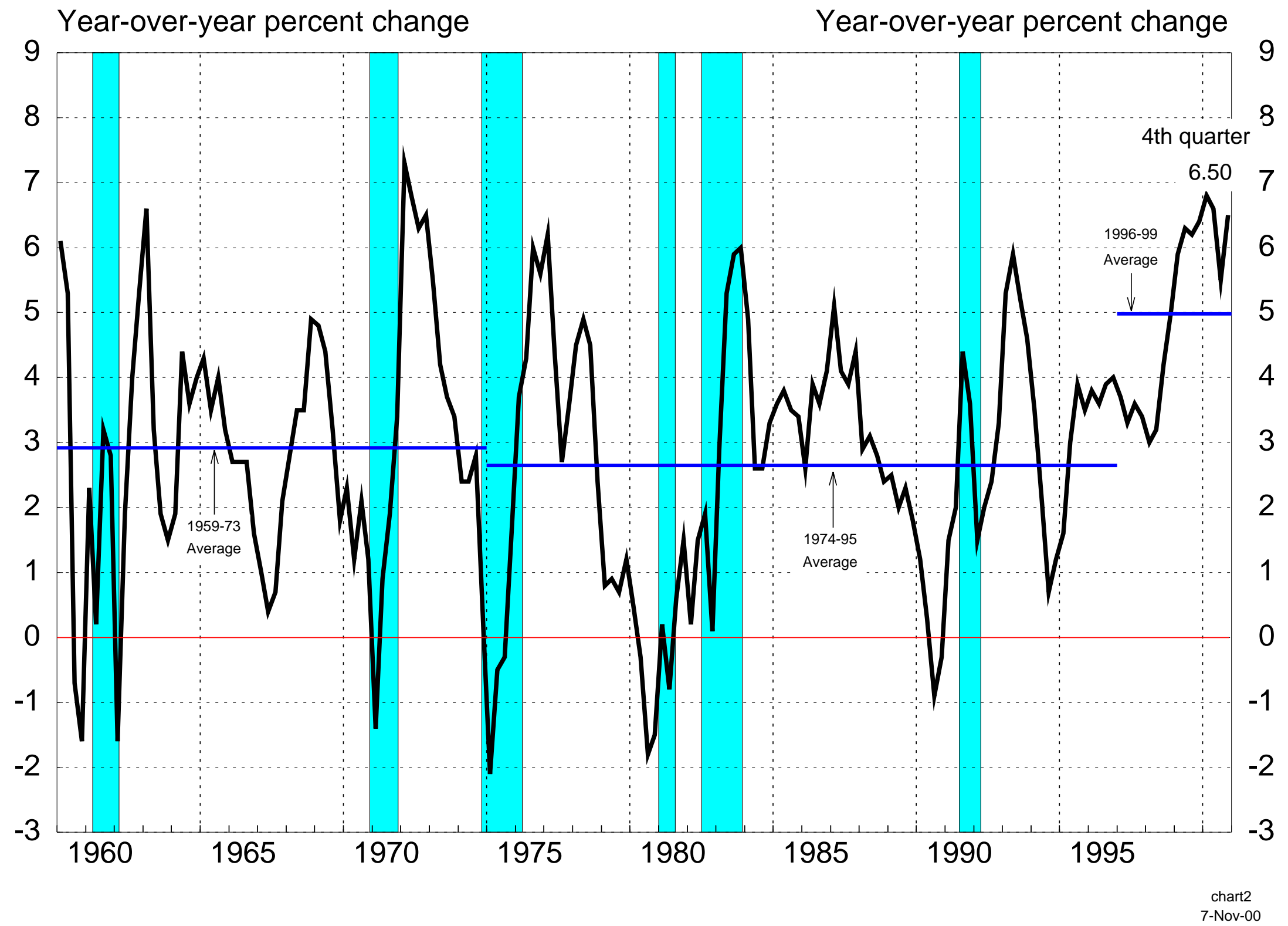




\section{NONFINANCIAL CORPORATE PRODUCTIVITY GROWTH}

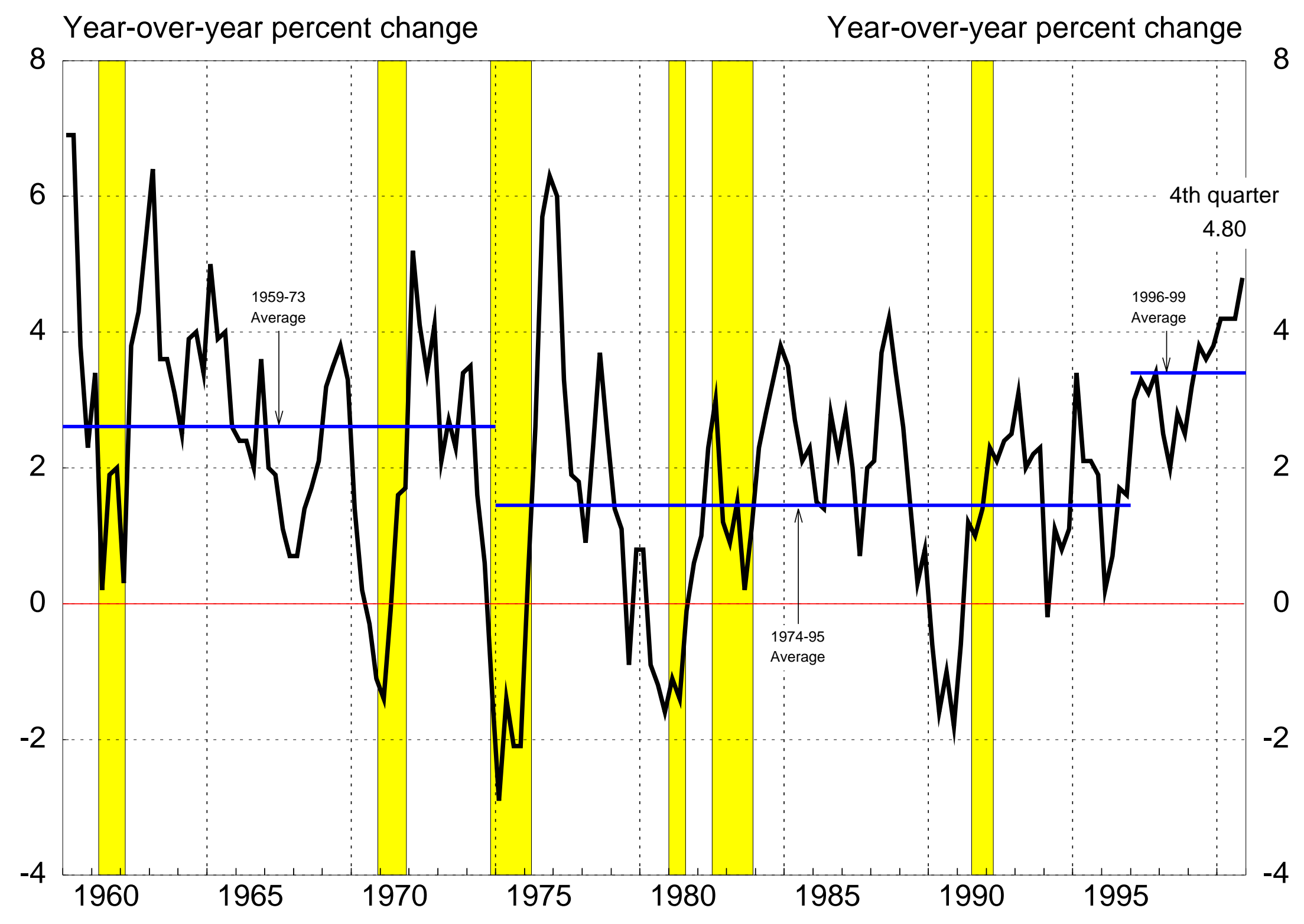




\section{MULTIFACTOR PRODU Chat 4 CTIVITY GROWTH}

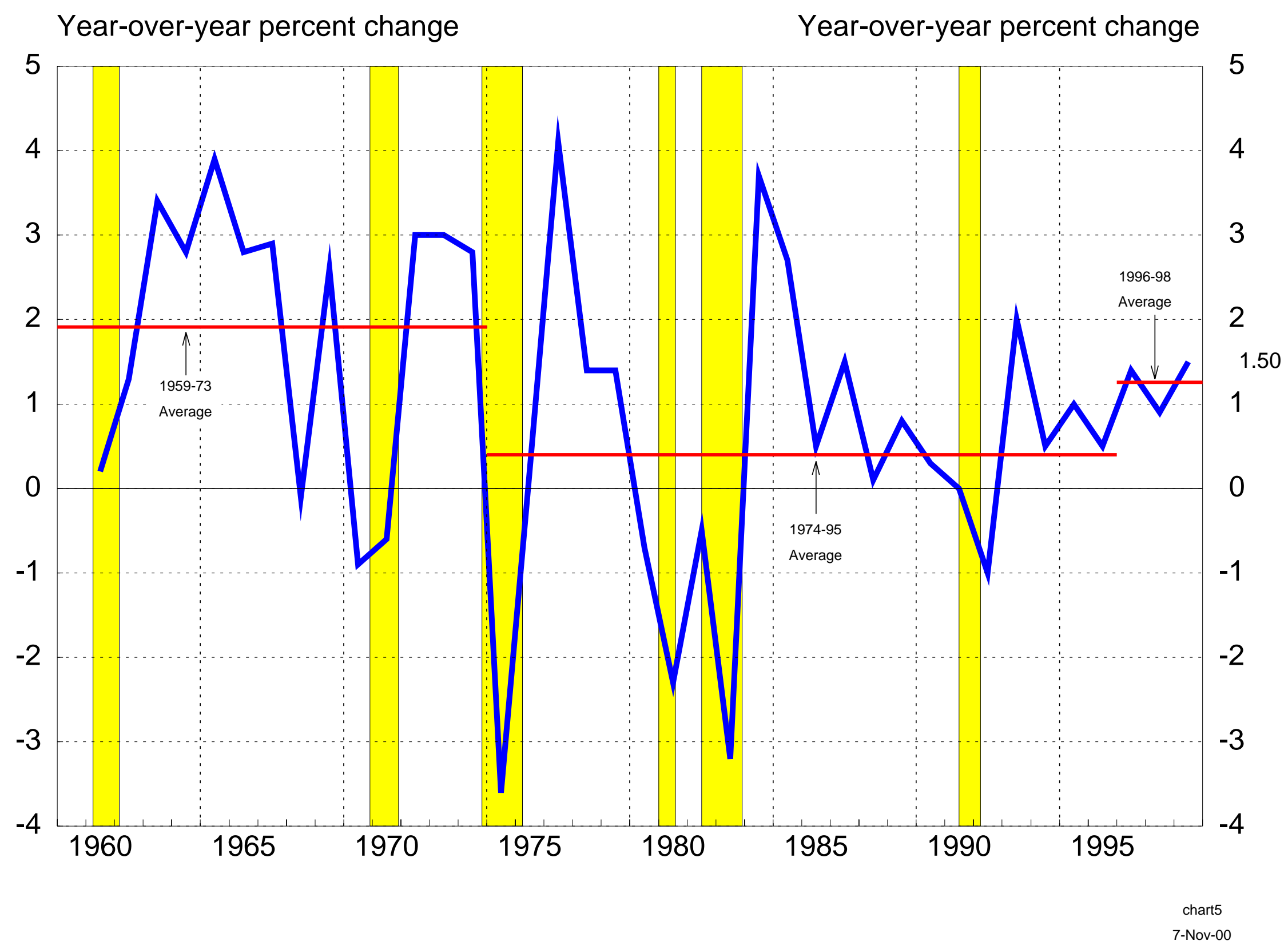




\section{OUTPUT GROWTH AND PRODUCTIVITY GROWTH \\ Year-to-Year Percent Change}
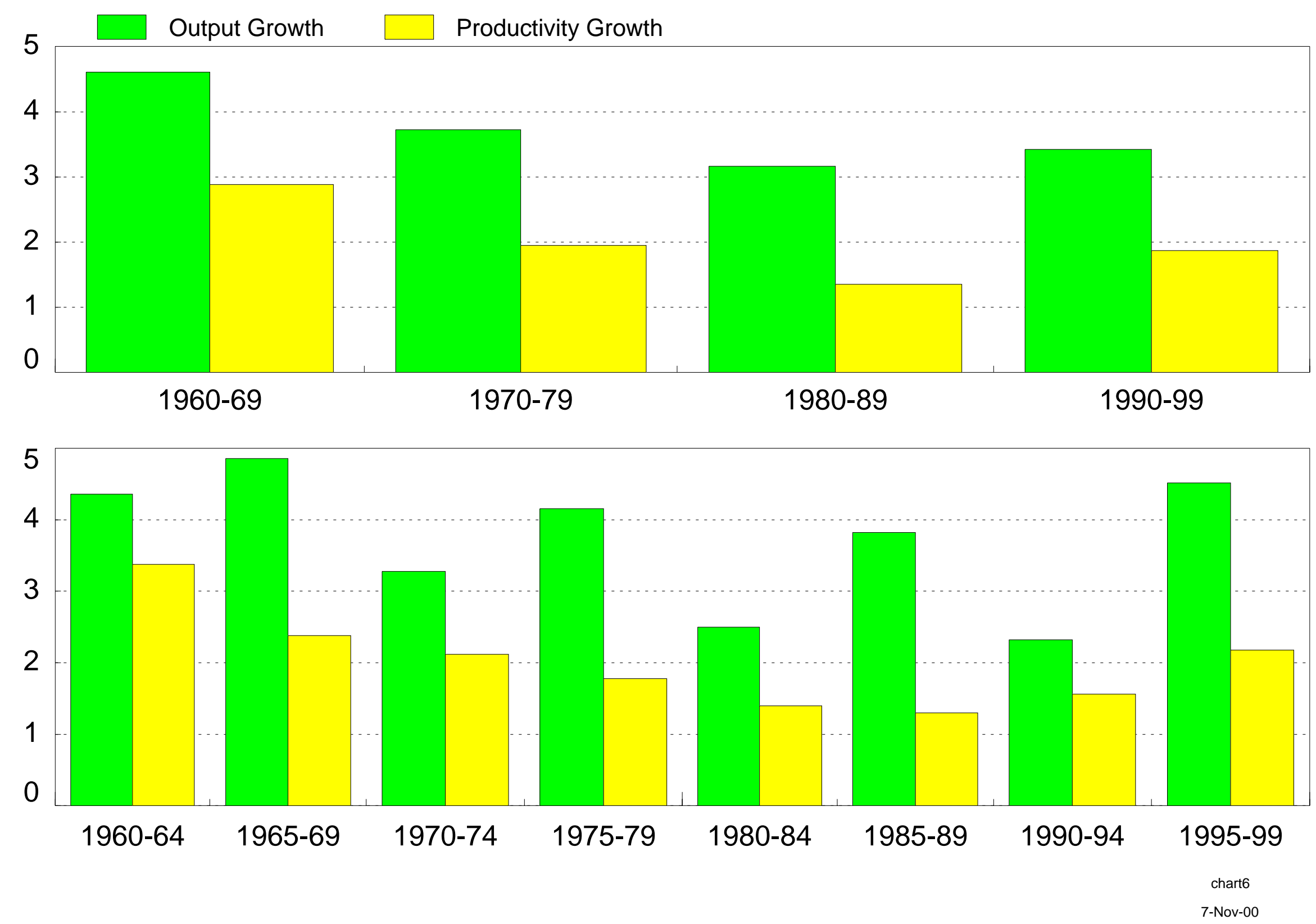
Correlation of Output Growth and Productivity Growth: 1969:Q1 to 1999:Q4

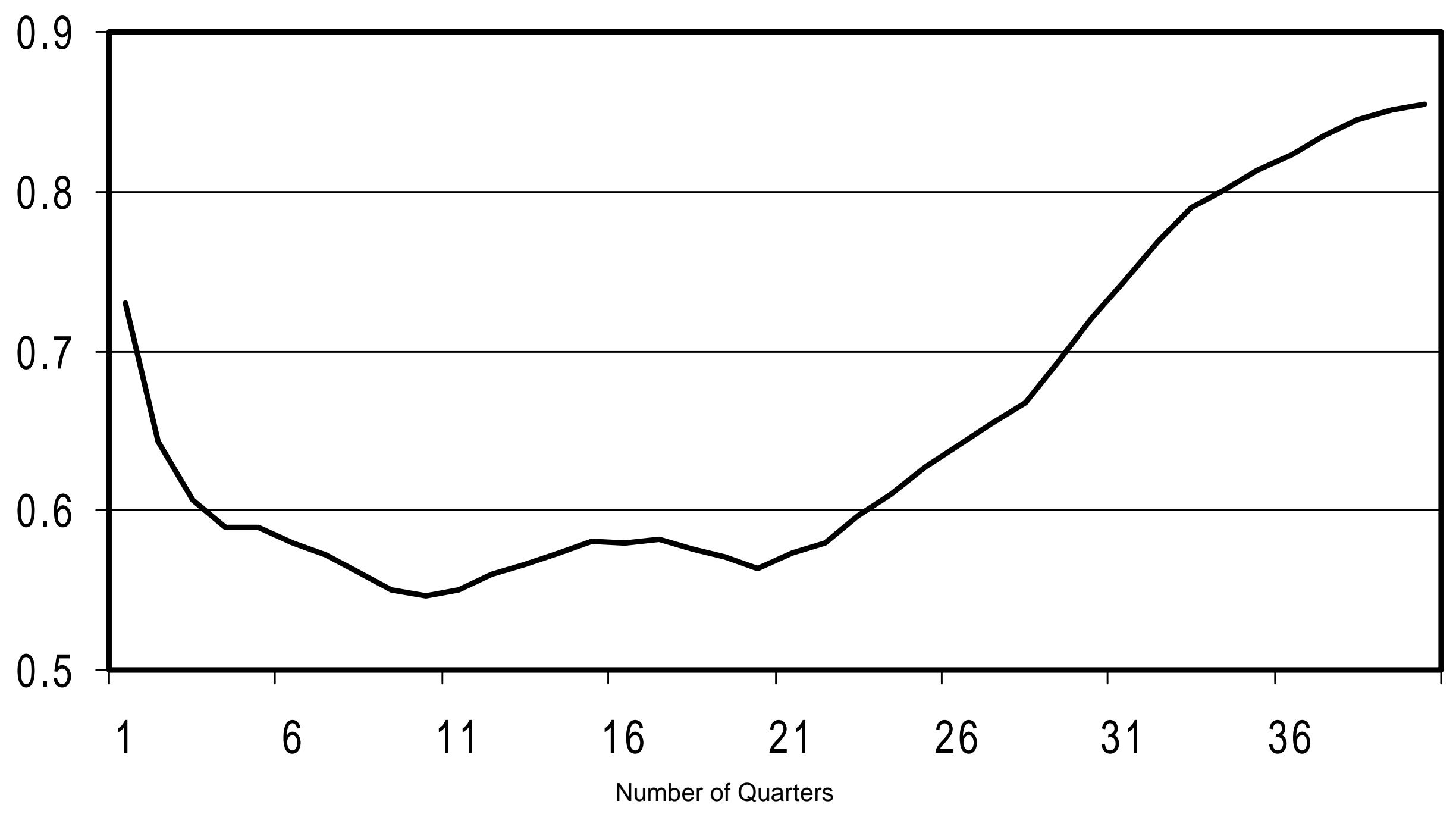


Correlation of Real Income Growth and Productivity Growth: 1969:Q1 to 1999:Q4

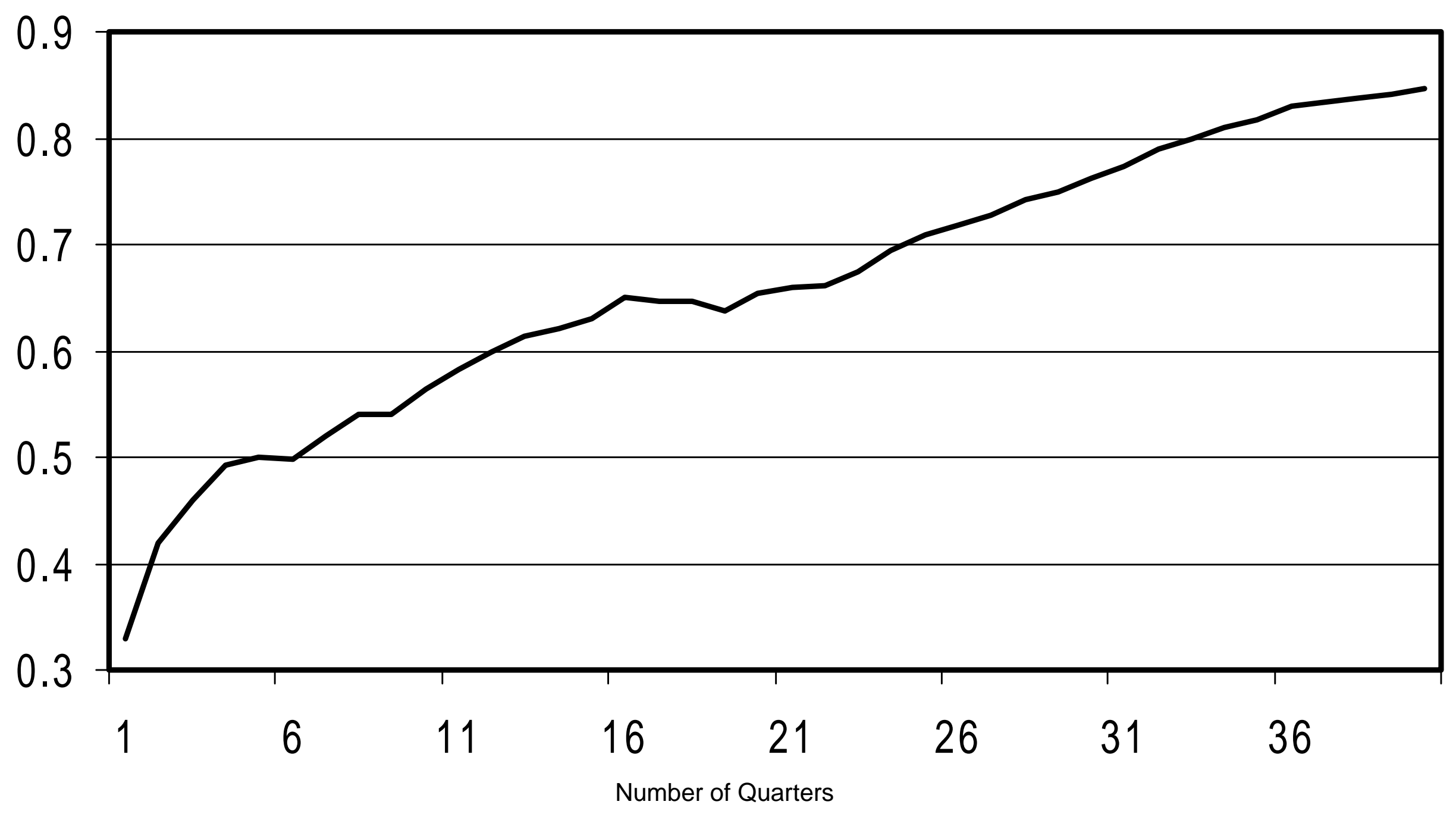




\section{Correlation of Inflation and Productivity Growth: 1969:Q1 to 1999:Q4}

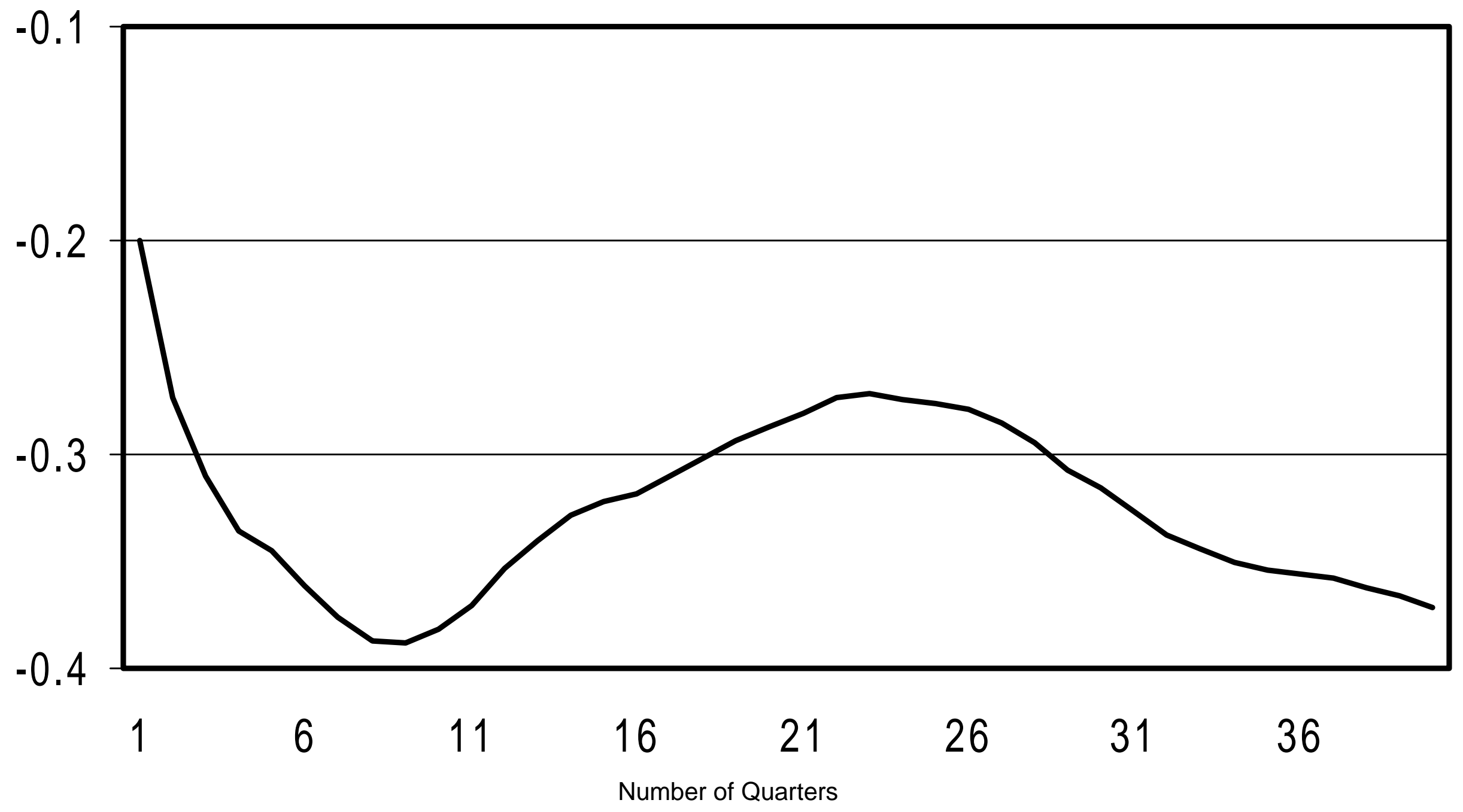


CHART 9

\section{Impulse Responses of Productivity and Macroeconomic Variables ${ }^{1}$}

Response to

Productivity Growth of: ${ }^{2}$


Response of

Productivity Growth to: ${ }^{3}$

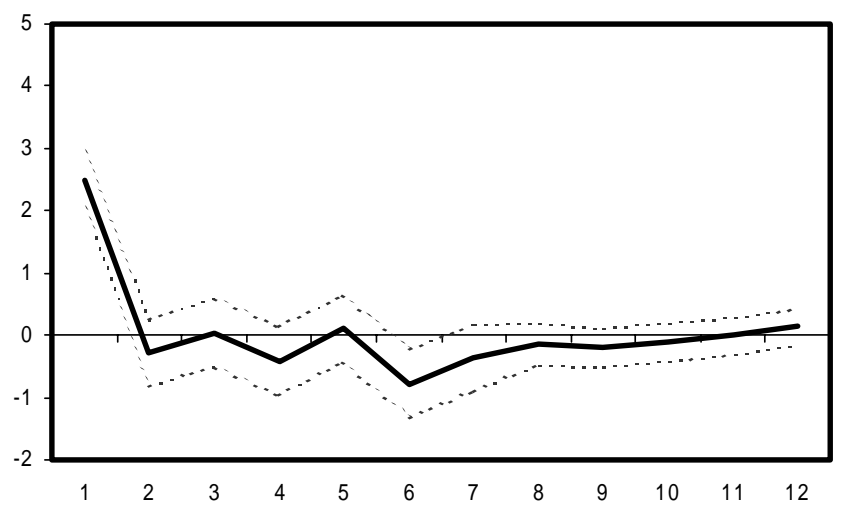

Real Output Growth
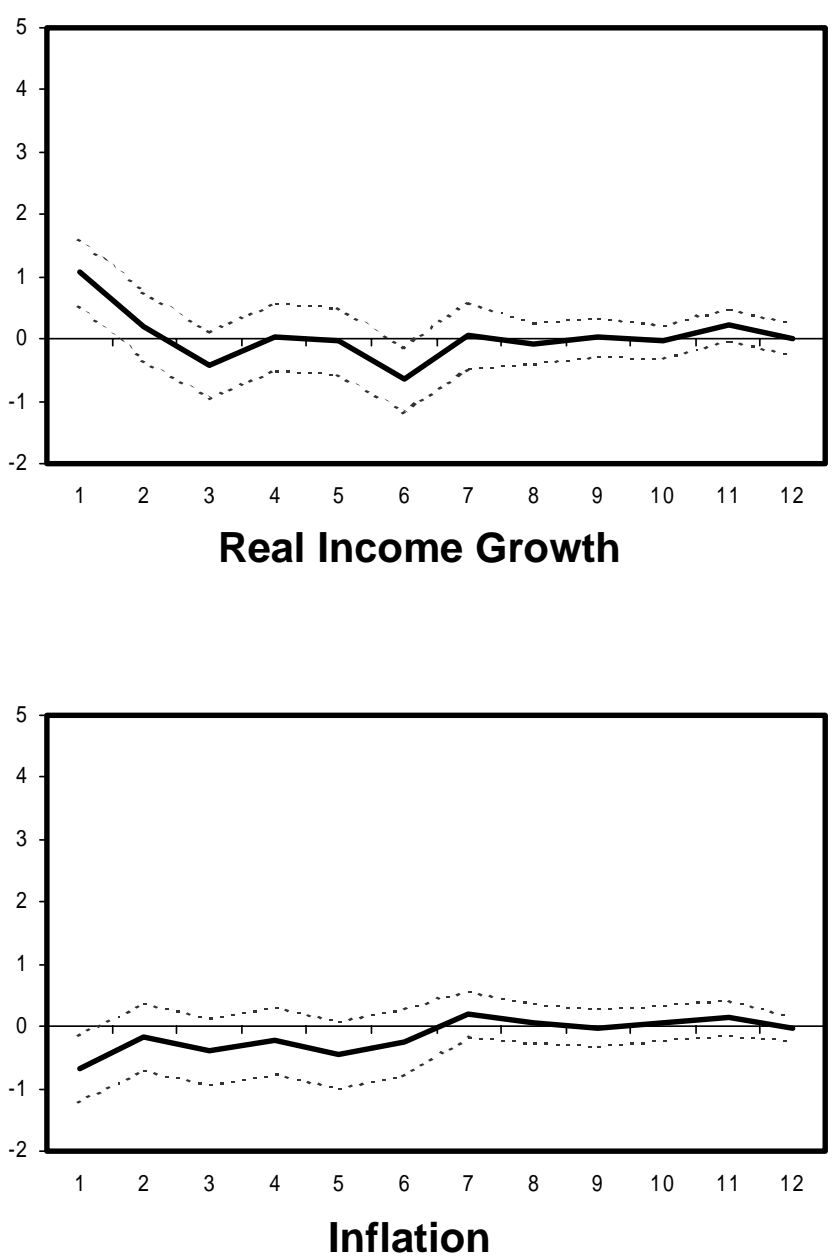

(1) All results from bivariate VARs estimated over 1969q1-1999q4 with 6 lags on each variable. Y-axis in standard deviation units.

(2) Taken from orderings with productivity growth shock first.

(3) Taken from orderings with productivity growth shock second. 


\section{Chart 10: Comparison of the Growth of Capital Stock and Services}

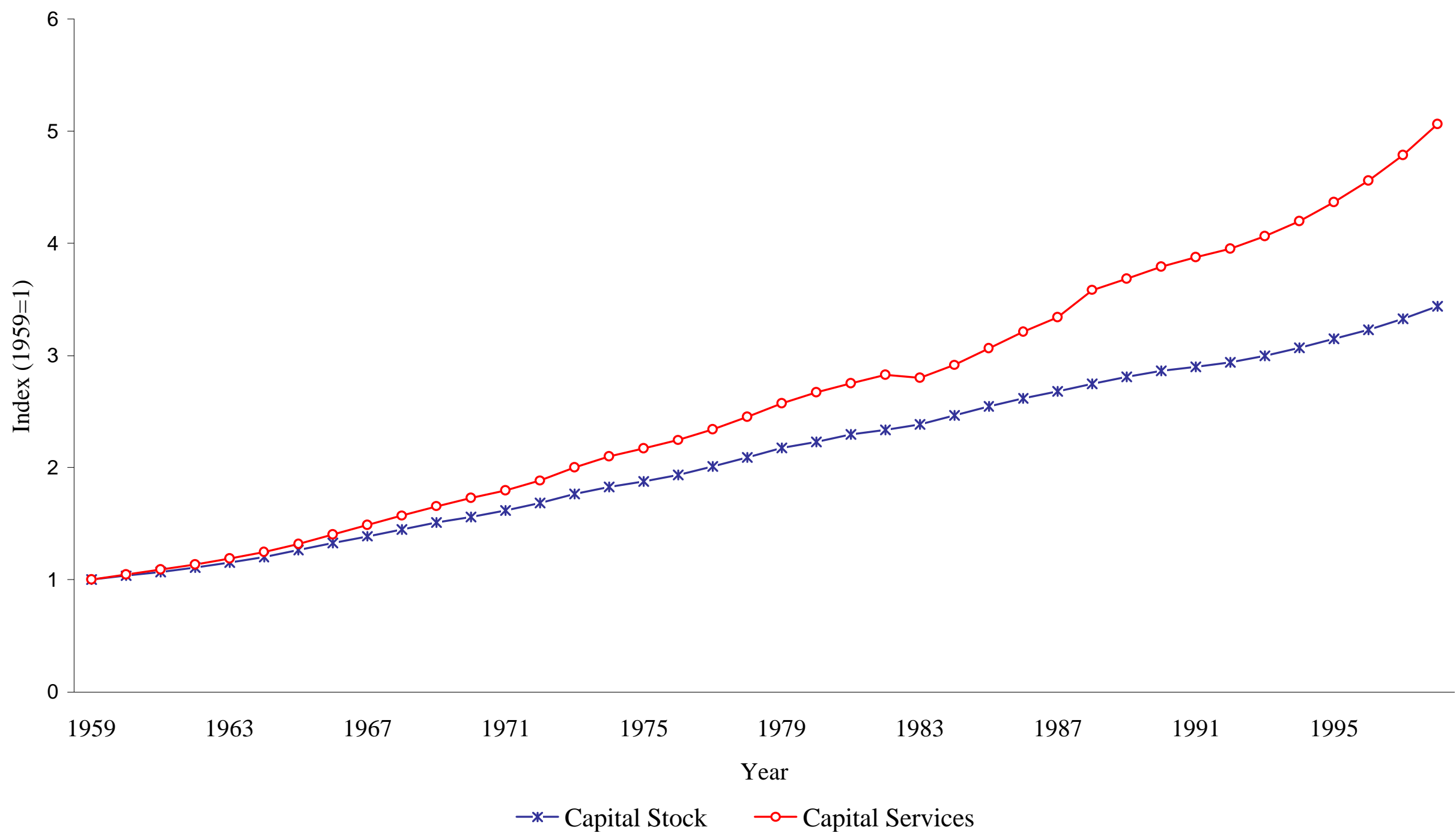

Source: Jorgenson and Stiroh (2000). 


\section{Chart 11: Comparison of the Growth of Labor Hours and Input}

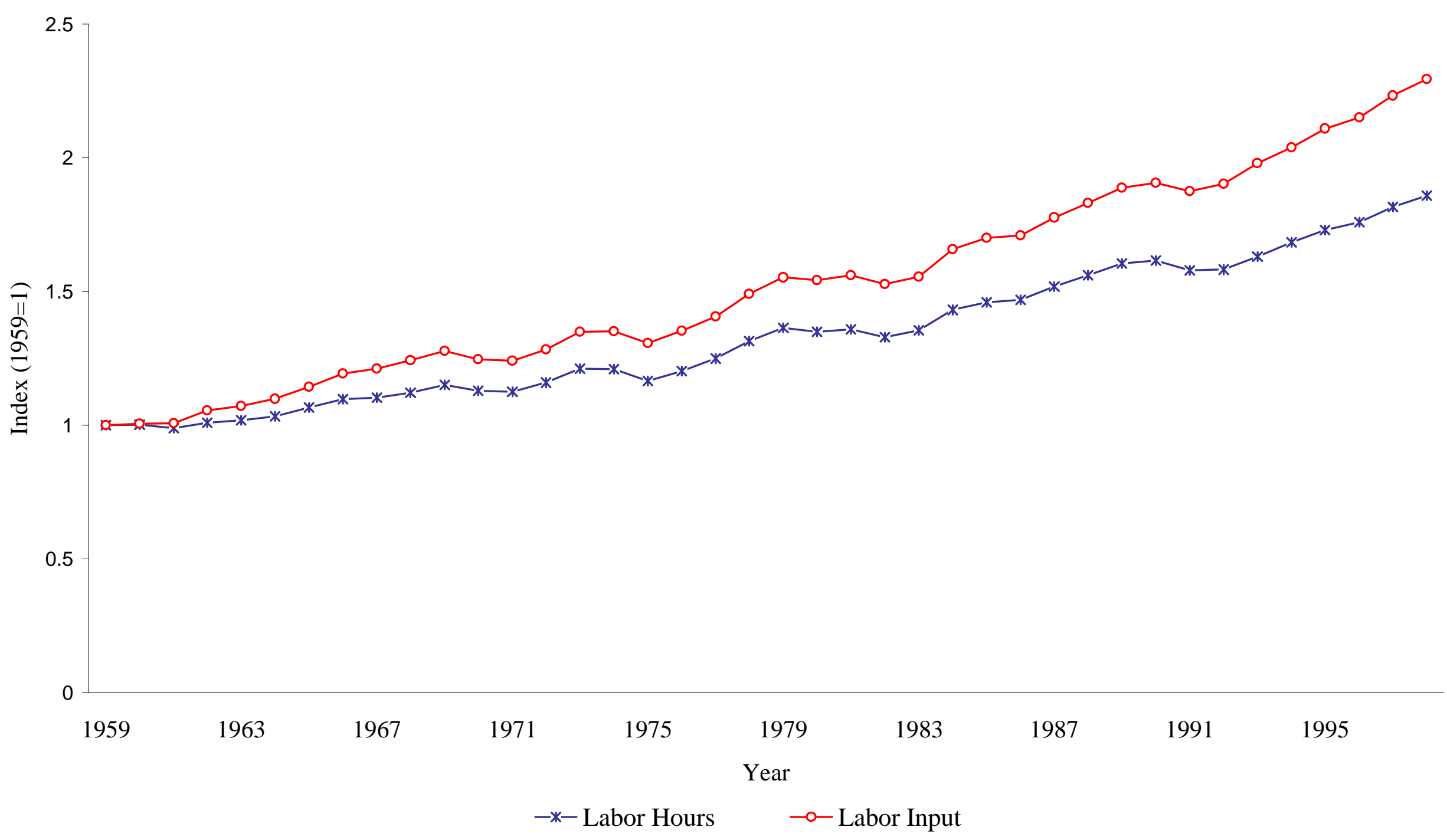

Source: Jorgenson and Stiroh (2000). 
Table 1: Average Productivity Growth Rates, 1959-99

$1959-73 \quad 1973-95 \quad 1995-99$

\section{Average Labor Productivity (ALP) Growth}

Nonfarm business (BLS)

2.97

1.35

2.45

Nonfarm business (BEA)

na na $\quad 2.03$

Manufacturing (BLS)

2.91

2.65

4.75

Business (Jorgenson and Stiroh)

2.95

1.42

2.58

Nonfarm business (Oliner and Sichel)

na

1.41

2.57

\section{Total Factor Productivity (TFP) Growth}

Nonfarm business (BLS)

$$
1.91
$$

0.40

1.26

Business (Jorgenson and Stiroh)

1.01

0.34

0.99

Nonfarm business (Oliner and Sichel)

na

0.36

1.16

Note: BEA nonfarm business ALP estimate is through 1998. BLS nonfarm business TFP estimate is through 1998. All values are percentages.

Source: BLS (2000b), BEA (2000), Jorgenson and Stiroh (2000), and Oliner and Sichel (2000). 
Table 2: Sources of Economic Growth, 1973-99

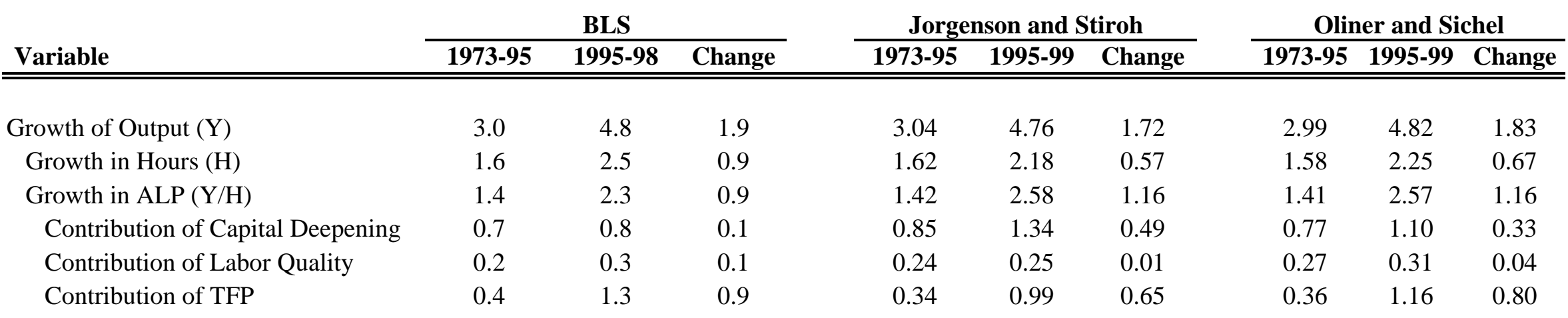

Notes: ALP Contributions are defined in Equation (1). All values are percentages. BLS estimates for nonfarm business sector through 1998 and numbers do not add precisely due to rounding.

Sources: BLS(2000b), Jorgenson and Stiroh (2000), and Oliner and Sichel (2000). 